\title{
Hubungan Dukungan Keluarga dengan Self Esteem pada Pasien Kanker Payudara di Poliklinik Bedah Onkologi RSUP Sanglah Denpasar
}

\author{
Ni Luh Putu Mahayani ${ }^{1}$, Ni Komang Sukraandani ${ }^{2}$, Ni Wayan Suniyadewi ${ }^{3}$ \\ ${ }^{1,2,3}$ Program Studi Ilmu Keperawatan STIKes Wira Medika Bali \\ Email:mahagole1979@gmail.com
}

Submitted : 02/03/2020

Accepted: 16/03/2020

Published: 07/09/2020

\begin{abstract}
Breast cancer sufferers have a tendency to experience a decrease of self esteem that make patients shall showing symptoms such as blaming themself for what they experienced. One way to increase self esteem in cancer patients is by increasing family participation through family support. The aim of this study is to determine the relationship between family support and self esteem in breast cancer patients. This study was using cross sectional design. The study was taken place at the Surgical Oncology Polyclinic, found samples of 188 respondents which was selected with a purposive sampling technique.The results showed that the majority of respondents were in the category of moderate self-esteem were 98 respondents (52.1\%) and the category of moderate family support were 96 respondents (51.1\%). The Rank Spearmen test results shows $p$ value 0,000 $(p<a)$, means there is a relationship between self-esteem and family support in breast cancer patients with $r$ value of 0.566 (positive relationship). It is expected that the family will always support the patient in every process of treatment, whether in the form of physical, psychological or financial support that could increase the patient's self esteem
\end{abstract}

Key Words: breast cancer, family support, self esteem

\begin{abstract}
Abstrak
Penderita kanker payudara memiliki kecendrungan mengalami penurunan self esteem sehingga pasien akan menunjukan gejala-gejalan seperti menyalahkan dirinya atas apa yang dialami. Salah satu cara meningkatkan self esteem pada pasien kanker adalah dengan cara meningkatkan peran serta keluarga melalui dukungan keluarga.Tujuan dari penelitian ini adalah untuk mengetahui hubungan antara dukungan keluarga dengan self esteem pada pasien kanker payudara. Penelitian ini menggunakan desain cross sectional. Penelitian dilakukan di Poliklinik Bedah Onkologi, jumlah sampel 188 responden yang dipiluh dengan teknik purposive sampling. Hasil penelitian menunjukkan sebagian besar responden berada pada kategori self esteem sedang yaitu sebanyak 98 responden $(52,1 \%)$ dan kategori dukungan keluarga sedang yaitu sebanyak 96 responden $(51,1 \%)$. Hasil uji Rank Spearmen diperoleh nilai $p$ value 0,000 $(p<a)$, yang berarti ada hubungan antara self esteem dengan dukungan keluarga pada pasien kanker payudara dengan nilai $r$ hitung sebesar 0,566 (hubungan positif). Diharapkan keluarga senantiasa mendukung pasien dalam setiap menjalankan proses pengobatan, baik berupa dukungan fisik, psikis maupun financial sehingga dapat meningkatkan self esteem pasien
\end{abstract}

Kata Kunci: dukungan keluarga, kanker payudara, self esteem

\section{PENDAHULUAN}

Kanker payudara merupakan ancaman yang serius bagi kesehatan masyarakat karena insiden dan angka kematiannya terus meningkat. Kanker payudara merupakan penyakit neoplasma yang bersifat ganas, dimana sel payudara mengalami proliferasi, diferensiasi abnormal dan tumbuh secara autonom yang menyebabkan infiltrasi ke jaringan sekitar merusak serta menyebar ke bagian tubuh yang lain (Smeltzer \& Bere, 2012).

Wanita yang menderita kanker payudara mengalami gangguan bukan pada fisik saja tetapi juga pada kondisi emosi dan mentalnya (Wahidin, 2015). Bagi wanita payudara tidak hanya organ penyusuan bayinya, namun merupakan organ daya 
tarik (attractiveness) bagi kaum pria. Sehingga setiap organ mempunyai arti psikologik tersendiri bagi masing-masing wanita. Oleh karena itu suatu tindakan pengobatan yeng mengakibatkan hilang atau cacatnya bagian tubuh, mempunyai nilai psikologik dan tidak dapat dihindarkan terjadi pula perubahan-perubahan terhadap self esteem pasien.

Penderita kanker payudara memiliki kecendrungan mengalami penurunan self esteem sehingga pasien akan menunjukan gejala-gejalan seperti menyalahkan dirinya atas apa yang dialami, berpandangan negatif terhadap dirinya, merasa tidak puas dengan kondisinya dan perasaan malu berbeda dengan wanita yang lain (Chris, 2005, dalam Sastra 2016).

Data International Agency for Research on Cancer (dalam Wahidin, 2015), menunjukan bahwa kanker payudara mempunyai insiden tertinggi nomor satu di seluruh dunia dengan angka kejadian 43,3\% dari 14.067.894 kasus baru kanker di seluruh dunia. Kanker payudara dan kanker paru merupakan penyebab kematian tertinggi untuk kasus kanker di seluruh dunia.

Berdasarkan data Riset Kesehatan Dasar tahun 2018 prevalensi kanker payudara menempati urutan pertama di Indonesia yaitu sebesar 42,1 per 100.000 penduduk dengan rata-rata kematian 17 per 100.000 penduduk, yang diikuti kanker leher rahim sebesar 23,4 per 100.000 penduduk dengan rata-rata kematian 13,9 per 100.000 penduduk. Prevalensi kanker payudara di Indonesia diperoleh data bahwa Provinsi Yogyakarta menempati urutan pertama jumlah kanker payudara tertinggi yaitu 2,4 per 1000 perempuan (4.325), selanjutnya diikuti oleh DKI Jakarta yaitu 0,8 per 1000 perempuan (3.946), Provinsi Sumatra Barat yaitu 0,9 per 1000 perempuan (2.285), Aceh 0,8 per 1.000 perempuan (1.869), dimana Provinsi Bali menempati urutan keempat angka kejadian kanker payudara tertinggi yaitu mencapai
0,6 per 1000 perempuan (1.233) (Riset Kesehatan Dasar, 2018)

Berdasarkan data Dinas Kesehatan Provinsi Bali (2018), kanker payudara menempati urutan pertama pasien kanker di Bali, dimana terjadi peningkatan persentase kasus setiap tahunnya. Pada tahun 2016 sebanyak $727(16,5 \%)$ pasien kanker payudara dari total 4.404 pasien kanker, tahun 2017 sebanyak 920 (20,76\%) kasus kanker payudara dari total 4.430 pasien kanker, dan tahun 2018 sebanyak 1020 $(24,56 \%)$ kanker payudara dari total 4.153 pasien kanker.

Berdasarkan data register pasien kanker di poliklinik bedah onkologi RSUP Sanglah Denpasar pada bulan Januari-Juni 2019 kanker payudara menempati urutan pertama jumlah kunjungan pasien kemoterapi di RSUP Sanglah Denpasar yaitu sebanyak 519 pasien, dimana diantaranya sebanyak 352 pasien merupakan pasien kanker payudara stadium II dan III.

Menurut Sudrajat (2012, dalam Oktavia, S.W, 2014), salah satu cara meningkatkan self esteem pada pasien kanker adalah dengan cara meningkatkan peran serta keluarga melalui dukungan keluarga. Pada keadaan psikologi yang kurang baik akibat kondisi fisik pasien kanker payudara sangat membutuhkan dukungan dari orang-orang terdekat seperti keluarga. Keluarga merupakan orang yang terdekat dengan pasien yang memberikan ketenangan dan kenyamanan dalam berbagai kondisi penyakit yang dialami pasien (Mubarak, 2012).

Berdasarkan hasil studi pendahuluan yang peneliti lakukan di Poliklinik Bedah Onkologi RSUP Sanglah Denpasar pada tanggal 1-3 Juli 2019 yang diperoleh data dari hasil penyebaran kuesioner self esteem terhadap 10 responden dimana 6 pasien $(60 \%)$ memiliki self esteem yang rendah, 2 pasien (20\%) memiliki self esteem sedang dan 2 pasien (20\%) memilik self esteem yang tinggi. Selanjutnya studi pendahuluan 
tentang dukungan keluarga terhadap 6 responden yang memiliki self esteem kategori rendah tersebut diperoleh data bahwa 3 orang memiliki dukungan keluarga yang kurang dan 3 orang memiliki dukungan keluarga sedang. Hal tersebut menunjukan bahwa pasien masih memiliki self esteem yang rendah dan membutuhkan dukungan dari keluarga.

Dukungan keluarga sebagai bentuk perhatian dan kasih sayang yang meliputi bio psiko sosial spiritual dan material terhadap pasien kanker payudara, sehingga baik buruknya dukungan keluarga akan berpengaruh terhadap self esteem pasien, oleh sebab itu peneliti tertarik untuk melakukan penelitian tentang hubungan antara dukungan keluarga dengan self esteem pada pasien kanker payudara di RSUP Sanglah Denpasar.

\section{METODE PENELITIAN}

Jenis penelitian yang digunakan adalah cross sectional yang bersifat analitik. Tempat penelitian ini adalah ruang Poliklinik Bedah Onkologi RSUP Sanglah Denpasar.Penelitian ini dilaksanakan pada tanggal 8-30 November 2019.

Populasi yang digunakan adalahseluruh pasien kanker payudara stadium II dan III yang berkunjung ke Poliklinik Bedah Onkologi RSUP Sanglah Denpasar pada tanggal 8-30 November 2019 yaitu sebanyak 352 pasien. Sampel penelitian ini sebanyak sebanyak 188 respondenyang memenuhi kriteria inklusi dan dipilih dengan teknik non probability (non random sampling) jenis purposive sampling

Penelitian ini menggunakan duavariabel yaitu variabel bebas (dukungan keluarg) danvariabel tergantung (self esteem).Instrumen pengumpulan data yang digunakan dalam penelitian ini yaitu lembar kuesioner. Kuesioner dukungan keluarga terdiri dari 12 pernyataan yang dikutip dari Nursalam (2011). Kuesioner self esteem dengan menggunakan skala Rosenberg versi Indonesia yang terdiri dari 10 item pernyataan yang mengukur secara umum penilaian self esteem secara positif dan negatif.

Teknik analisa data yang digunakan dalam penelitian ini analisis univariat dan bivariat. analisis univariat digunakan untuk menggambarkan distribusi frekuensi karakteristik responden (umur, pendidikan dan status perkawinan), variabel dukungan keluarga, serta variabel self esteemyang disajikan dalam bentuk tabel distribusi frekuensi.Pada penelitian ini analisis bivariat digunakan untuk menguji ada tidaknya hubungan antara variabeldengan menggunakan uji Korelasi Rank Spearmen dengan tingkat kepercayaan $\alpha=0,05$ dan diperoleh $P$-value $<\alpha$, sehingga Ho ditolak.

\section{HASIL DAN PEMBAHASAN}

Karakteristik responden berdasarkan umur dijelaskan pada tabel 1 sebagai berikut.

Tabel 1. Karakteristik Responden

Berdasarkan Umur

\begin{tabular}{cccc}
\hline \multirow{2}{*}{ No } & Umur Responden & \multicolumn{2}{c}{ Responden } \\
\cline { 3 - 4 } & & $\mathrm{f}$ & $\%$ \\
\hline 1 & $>18$ tahun -45 & 30 & 16, \\
& tahun & & 0 \\
2 & $46-59$ tahun & 119 & 63, \\
& & & 3 \\
3 & & 39 & 20, \\
& & & 7 \\
\hline \multirow{2}{*}{ 60 tahun } & 188 & 10 \\
& Total & & 0 \\
\hline
\end{tabular}

Penelitian Robin et all (2002 dalam Anggraeni, dkk, 2016) yang meneliti tentang hubungan self esteem dengan usia yang dilakukan dengan melibatkan 326.641 responden, dengan rentang usia 9 hingga 90 tahun, disebutkan bahwa self esteem cenderung meningkat di rentang usia 40-60 tahun.

Berdasarkan hasil penelitian Halimatussakdiah \& Junardi (2017) dalam penelitiannya pada Pasien Kanker 
Payudara, dimana hasil penelitian menunjukan bahwa sebagian besar responden berada pada rentang umur $>35$ tahun yaitu sebanyak 62 responden (95,4\%). Menurut Potter dan Perry (2010) umur 46- 59 tahun kedalam usia dewasa lanjut yang secara psikologis telah mencapai perkembangan kognitif yang optimal.

Notoatmodjo

mengemukakan bahwa semakin tua umur seseorang maka proses-proses pekembangan mentalnya bertambah baik, akan tetapi pada usia tertentu, bertambahnya proses perkembangan mental ini tidak secepat seperti ketika berusia belasan tahun. Bertambahnya usia seseorang berpengaruh pada pertambahan pengetahuan dan perilaku seseorang, akan tetapi pada usia-usia tertentu atau menjelang usia lanjut kemampuan penerimaan atau mengingat pengetahuan akan berkurang.

Karakteristik responden berdasarkan pendidikandijelaskan pada tabel 2

Tabel 2. Karakteristik Responden

Berdasarkan Pendidikan

\begin{tabular}{|c|c|c|c|}
\hline & \multirow{2}{*}{$\begin{array}{l}\text { Pendidikan } \\
\text { Responden }\end{array}$} & \multicolumn{2}{|c|}{ Responden } \\
\hline & & $\mathrm{f}$ & $\%$ \\
\hline 1 & tidak sekolah & 1 & 0,5 \\
\hline 2 & SD & 6 & 3,2 \\
\hline 3 & SLTP & 32 & 17,0 \\
\hline 4 & SLTA & 81 & 43,1 \\
\hline 5 & $\begin{array}{l}\text { Diploma/Perguran } \\
\text { Tinggi }\end{array}$ & 68 & 36,2 \\
\hline & Total & 188 & 100 \\
\hline
\end{tabular}

Hasil penelitian ini sesuai dengan hasil penelitian Suwistianisa. R , dkk (2015), dimana hasil penelitian menunjukkan bahwa mayoritas responden memiliki tingkat pendidikan SMA sebanyak 23 responden (38,3\%). Hasil yang sama juga ditunjukan oleh penelitian Halimatussakdiah \& Junardi (2017), dimana hasil penelitian menunjukan sebagian besar responden berada pada kategori pendidikan menengah (SLTA) sebanyak $32(49,2 \%)$.
Menurut Notoatmodjo

(2009) pendidikan seseorang secara tidak langsung akan mempengaruhi kemampuan beradaptasi terhadap stresor dan keberhasilan dalam berpartisipasi akan menimbulkan self esteem yang tinggi. Individu dengan self esteem yang tinggi akan mencapai prestasi akademik yang tinggi dibanding individu dengan self esteem yang rendah, karena individu dengan self esteem tinggi memiliki skor intelegensi yang lebih baik dan selalu berusaha keras (Ghufron, 2010 dalam Sudana, Chrisnawati, dan Maratning, 2016).

Karakteristik responden berdasarkan status perkawinan dijelaskan pada tabel 3

Tabel 3. Karakteristik Responden Berdasarkan Status Perkawinan

\begin{tabular}{cccc}
\hline \multirow{2}{*}{ No } & Status Perkawinan & \multicolumn{2}{c}{ Responden } \\
\cline { 3 - 4 } & & $\mathrm{f}$ & $\%$ \\
\hline 1 & Belum menikah & 10 & 5,3 \\
2 & Sudah menikah & 164 & 87, \\
& & & 2 \\
3 & Janda & 14 & 7,4 \\
\hline \multirow{2}{*}{} & Total & 188 & 10 \\
& & & 0 \\
\hline & Notoatmodjo & $(2009)$ & yang
\end{tabular}
menyatakan bahwa orang yang berstatus sudah menikah memiliki keluarga yang utuh, yang memberikan dukungan dalam setiap proses pengobatan pasien. Dukungan keluarga yang kuat atau tinggi akan mampu meningkatkan self esteem pasien sehingga akan membantu dalam proses perilaku pasien untuk meningkatkan derajat kesehatannya. Hal ini sesuai dengan hasil penelitian Pristiwati, A , Aniroh. U, Wakhid. A., (2018), dimana hasil penelitian menunjukan bahwa dukungan keluarga terbukti mampu meningkatkan respon psikologis pasien.

Berdasarkan karakteristik responden, maka peneliti berpendapat bahwa umur, pendidikan dan status perkawinan berhubungan dengan self esteem dan dukungan keluarga, namun hal ini belum dapat dibuktikan karena peneliti belum 
melakukan analisa data korelasi secara statistik antara karakteristik responden dengan self esteem dan dukungan keluarga. Dimana berdasarkan hasil penelitian ini menunjukan bahwa responden dengan kategori umur dewasa akhir, tingkat pendidikan tinggi dan yang berstatus sudah menikah cenderung memiliki tingkat self esteem yang lebih tinggi dari pada responden dengan kategori yang lain

Identifikasi Self Esteem Pasien Kanker Payudara dalam Menjalani Kemoterapi

Hasil distribusi frekuensi self esteem pasien kanker payudara dalam menjalani kemoterapi dapat dilihat pada tabel 4 . Sebagian besar responden berada pada kategori self esteem kategori sedang yaitu sebanyak 9 responden $(52,1 \%)$. Hasil penelitian ini menunjukan bahwa terdapat $0,5 \%$ yang memiliki self esteem rendah, hal ini membuktikan bahwa seseorang yang menderita kanker payudara dapat mengalami penurunan self esteem yang dapat digambarkan sebagai perasaan negatif terhadap dirinya sendiri, hilang percaya diri, merasa gagal dalam mencapai keinginan, pesimis, merasa lebih buruk dibandingkan orang lain, dan menyalahkan diri sendiri atas apa yang dialaminya (Hartati, 2008 dalam Sudana, Chrisnawati, dan Maratning, 2016).

Tabel 4. Identifikasi self esteem pasien kanker payudara dalam menjalani kemoterapi

\begin{tabular}{llcc}
\hline \multirow{2}{*}{ No } & self esteem & \multicolumn{2}{c}{ Responden } \\
\cline { 3 - 4 } & & $\mathrm{F}$ & $\%$ \\
\hline 1 & Rendah & 1 & 0,5 \\
2 & Sedang & 98 & 52,1 \\
3 & Tinggi & 89 & 47,3 \\
\hline & Total & 188 & 100 \\
\hline
\end{tabular}

Hasil penelitian ini didukung oleh penelitian Sudana, Chrisnawati, dan Maratning (2016), dimana hasil penelitian menunjukan bahwa memiliki sebagian besar responden mempunyai harga diri tinggi yaitu sebanyak 53,3\% dan sebanyak $46,7 \%$ memiliki harga diri sedang. Hasil penelitian yang berbeda disampaikan oleh Ismaniar, E. (2017), dimana hasil penelitian menunjukan hasil $93 \%$ responden memiliki self esteem yang tinggi.

Berdasarkan hasil penelitian ini, peneliti berpendapat bahwa responden yang memiliki self esteem kategori sedang atau rendah akan cenderung mempengaruhi proses kesembuhan pasien. Dimana responden yang mengalami penurunan self esteem akan mengalami penurunan motivasi untuk sembuh sehingga pasien akan merasa tidak yakin bahwa dirinya dapat menjalani pengobatan dengan baik sehingga menurunkan potensi pasien untuk sembuh.

\section{Identifikasi Dukungan Keluarga Pada Pasien Kanker Payudara Dalam Menjalani Kemoterapi}

Hasil distribusi dukungan keluarga pasien dalam menjalani kemoterapisebagai berikut:

Tabel 5. Dukungan Keluarga Pasien dalam Menjalani Kemoterapi

\begin{tabular}{|c|c|c|c|}
\hline $\mathrm{N}$ & Dukungan Keluarga & \multicolumn{2}{|c|}{ Responden } \\
\hline o & & $\mathrm{f}$ & $\%$ \\
\hline 1 & Rendah & 4 & 2,1 \\
\hline 2 & Sedang & 96 & 51, \\
\hline 3 & Tinggi & 88 & $\begin{array}{c}46 \\
8\end{array}$ \\
\hline & Total & 188 & 100 \\
\hline
\end{tabular}

Berdasarkan tabel diatas sebagian besar responden berada dalam kategori dukungan keluarga sedang yaitu sebanyak 96 responden $(51,1 \%)$. Dukungan keluarga sangat diperlukan pada pasien kanker payudara dalam menjalani kemoterapi, agar dapat lebih meningkatkan semangat hidup atau motivasi dalam diri pasien kanker payudara dalam menjalani kemoterapi. Pendapat tersebut sesuai dengan hasil penelitian ini yang menunjukan bahwa dari keempat responden yang memiliki dukungan keluarga rendah, terdapat 3 responden yang berstatus janda. Hal ini membuktikan bahwa dukungan keluarga terutama suami, sangat berpengaruh 
terhadap pelaksanaan pengobatan kanker payudara (Friedman, M., 2010)

Menurut ahli Onkologi Liave \& Rosa dalam Yeny, dkk (2016), keluarga adalah teman terbaik bagi pasien kanker dalam menghadapi pertempuran dengan penyakitnya. Dukungan keluarga terhadap pasien kanker sangat dibutuhkan guna mengangkat mental dan semangat hidup pasien. Lebih lanjut Rosa mengatakan kanker adalah penyakit keluarga, dimana setiap orang yang terkena kanker akan berpengaruh juga kepada seluruh keluarga baik berupa emosional, psikologis, finansial maupun fisik.

Hal ini sesuai dengan hasil penelitian yang dilakukan oleh Kuijer, et al (dalam Sari, M dkk, 2014), yang mengatakan bahwa dukungan keluarga mempengaruhi kesembuhan ibu yang mengidap kanker payudara. Jadi bagi pasien kanker payudara yang mendapatkan dukungan dari keluarga mereka lebih bersemangat untuk menjalani kemoterapi dan pengobatan lainnya, sehingga hal ini dapat membantu mempercepat proses penyembuhannya.

Hasil penelitian ini sesuai dengan penelitian Yeny, dkk (2016) dalam penelitiannya yang berjudul Dukungan Keluarga Mempegaruhi Kepatuhan Pasien Hipertensi, dimana diperoleh sebagain besar responden masuk dalam kriteria dukungan keluarga kategori sedang sebanyak 32 responden (54\%). Hasil penelitian ini berbeda dengan hasil penelitian Lusiatun, dkk (2016), dimana hasil penelitian menunjukan bahwa sebagian besar masuk dalam kategori dukungan keluarga kuat. Hasil yang berbeda juga diungkapkan oleh Husni. M, dkk (2015), dimana hasil penelitian ini menunjukan bahwa sebagian besar responden masuk dalam kreteria dukungan kurang baik sebanyak 24 responden (75\%). Hasil penelitian yang sama ditunjukan oleh Suyanto, Pramesty. N, \& Arumdari P (2017) dimana sebanyak 98 responden
$(81,7 \%)$ mendapatkan dukungan keluarga dalam tingkatan sedang.

Berdasarkan hal tersebut, peneliti berpendapat bahwa terdapat 4 responden $(1,6 \%)$ yang memiliki dukungan keluarga yang kurang. Hal ini disebabkan karena beberapa faktor yang mempengaruhi seperti karakteristik responden itu sendiri, latar belakang budaya keluarga, fungsi keluarga, serta konflik yang ada dalam keluarga tersebut. Selain itu tiga orang responden dengan dukungan keluarga yang kurang tersebut berstatus janda, sehingga kemungkinan tidak ada dukungan dari kelaurga terutama suami sebagai orang terdekat.

\section{HubunganSelf Esteem dengan Dukungan Keluarga pada Pasien Kanker Payudara} Analisis hubungan Self Esteem dengan Dukungan Keluarga pada Pasien Kanker Payudara berdasarkan hasil uji Rank Spearman diperoleh nilai $p$ value $0,000(p<a)$, sehingga dapat disimpulkan bahwa ada hubungan antara self esteem dengan dukungan keluarga pada pasien kanker payudara. Berdasarkan tabel diatas dapat dilihat nilai $r$ hitung sebesar 0,566 yang artinya arah korelasi antara kedua variabel adalah positif (semakin tinggi dukungan keluarga maka semakin tinggi self esteem pada pasien kanker payudara) dengan kekuatan hubungan yang sedang. Henriksson dan Arestedt (2013, dalam Anggraini, dkk., 2016) menyatakan bahwa pasien kanker yang diberikan dukungan keluarga berupa dukungan emosional; misalnya dengan memberikan perhatian, kasih sayang, dan empati, dukungan instrumental; misalnya dengan memberikan bantuan tenaga, dana, dan waktu, dukungan informasional; dengan memberikan saran nasihat, juga informasi, dan terakhir dukungan penghargaan; misalnya dengan memberikan umpan balik dan menghargai, jika semuanya terpenuhi maka kualitas hidup pasien kanker akan meningkat dan secara tidak langsung akan 
meningkatkan self esteem pasien (Rosenberg, 1995, dalam dalam Irawati, 2016)

Dukungan keluarga membuat penderita kanker payudara merasa diterima dalam suatu komunitas baik itu di dalam rumah sakit maupun di luar rumah sakit, keluarga dapat mengajak mereka berbagi pengalaman atau melakukan aktifitas bersama-sama, membuat penderita kanker payudara tidak merasa menjadi satu-satunya yang mengalami penderitaan di dunia ini sehinggaself esteem pasien akan meningkat. Peningkatan self esteem akan membantu pasien mencapai derajat kesehatan yang maksimal. Hal ini sesuai dengan pendapat Stuart, G.W., and Sundenen, S.J. (2013) yang menyatakan bahwa, selain kondisi fisik maka kondisi psikologis juga memegang peranan penting dalam proses kesembuhan pasien (Rosenberg, 1995, dalam Irawati, 2016).Hasil penelitian Anggina, L. L., Hamzah, A., Pandhit (2010) menyatakan bahwa dukungan sosial keluarga dapat memberikan hasil yang positif terhadap kesehatan dan kesejahteraan pada pasien kanker payudara. Hal yang sama dinyatakan oleh Husni, Romadoni, Rukiyati (2015) bahwa dukungan positif yang diberikan keluarga dapat membuat pasien kanker payudara lebih kuat dalam melawan kanker tersebut.

Pada penelitian ini terdapat 1 responden yang memiliki self esteem yang rendah dan 4 orang memiliki dukungan keluarga rendah, hal tersebut disebabkan karena dengan dukungan keluarga yang rendah menurunnya self esttem pasien. Melalui dukungan keluarga maka akan dapat memberikan dukungan baik moril maupun materil untuk memotivasi orang tersebut dalam melaksanakan pengobatan pada pasien kanker payudara yang membutuhkan waktu yang cukup panjang.

\section{SIMPULAN}

Mayoritas responden berada pada kategori umur 46-59 tahun yaitu sebanyak
119 responden $(63,3 \%)$, mayoritas responden berpendidiakan tamat SLTA yaitu sebanyak 81 responden $(43,1 \%)$, dan mayoritas responden dengan status perkawinan sudah menikah yaitu sebanyak 164 responden $(87,2 \%)$.

Self esteem pada pasien kanker payudara diperoleh sebagian besar responden berada pada kategori self esteem kategori sedang yaitu sebanyak 98 responden $(52,1 \%)$

Dukungan keluarga pasien dalam menjalani kemoterapi diperoleh sebagian besar responden berada pada kategori dukungan keluarga sedang yaitu sebanyak 96 responden $(51,1 \%)$.

Hasil analisis data diperoleh nilai $p$ value $0,000(p<\mathrm{a})$ yang artinya ada hubungan antara self esteem dengan dukungan keluarga pada pasien kanker payudara dengan nilai $r$ hitung sebesar 0,566 yang artinya arah korelasi antara kedua variabel adalah positif yaitu semakin tinggi dukungan keluarga maka semakin tinggi self esteem pada pasien kanker payudara dengan kekuatan hubungan yang sedang.

Diharapkan keluarga senantiasa mendukung pasien dalam setiap menjalankan proses pengobatan, baik berupa dukungan fisik, psikis maupun financial sehingga dapat meningkatkan self esteem pasien. Peran perawat dan rumah sakit juga pentinhagar melakukan bimbingan psikologis dan edukasi secara berkelanjutan kepada pasien kanker payudara sehingga mampu meningkatkan self esteem yang pada akhirnya akan membantu proses penyembuhan

\section{DAFTAR PUSTAKA}

Anggina, L. L., Hamzah, A., Pandhit. 2010. Hubungan Antara Dukungan Keluarga

Irawati. R.I. 2012. Gambaran Harga Diri Siswa Tunanetra di Sekolah Luar Biasa TPA Bintaro Kabupaten 
Jember.

Available: Potter,

P.A.\&

Perry,

A.G.2010.

http://www.Repository_universitasje mber (9 Juli 2019).

Ismaniar, E. 2017. Hubungan Harga Diri dengan Kepuasan Seksual Pada Pasien Kanker Payudara di Rumah Sakit Pendidikan Universitas Hasanuddin Makassar. Available: http://digilib.unhas.ac.id/ uploaded_files/temporary /DigitalCollection/OTM5MjI2NmI3 MjEzMjE3OTNmYTNjZmM2YzZm Y2FlMmNmODA1MjcyOA==.pdf (10 September 2019).

Lusiatun, Mudigd. A, Murti. B. 2016. The Effect of Self-Efficacy, Family Support, and Socio Economic Factors on the Quality of Life of Patients with Breast Cancer at Dr. Moewardi Hospital, Surakarta. Journal of Epidemiology and Public Health 1(3): p.182-194.

Mubarak, W. dkk. 2012. Ilmu Keperawatan Komunitas 2; konsep dan aplikasi. Jakarta : Salemba Medika.

Notoatmodjo, S. 2009. Kesehatan Masyarakat. Ilmu \& Seni. Jakarta: PT. Rineka Cipta.

Nursalam. 2011. Konsep Dan Penerapan Metodelogi Penelitian Ilmu Keperawatan Pedoman Skripsi, Tesis, Dan Instument Penelitian Keperawatan Edisi 2. Jakarta: Salemba Medika.

Oktavia, S.W. 2014. Hubungan Antara Dukungan Sosial Keluarga Terhadap Tingkat Self Esteem Pada Penderita Pasca Stroke. JURNAL Psikologi Pendidikan dan Perkembangan Volume 3, No. 2,p. 110-118.
Fundamental Keperawatan (Konsep, Proses dan Praktik). Jakarta: EGC.

Pristiwati, Aniroh, \&Wakhid. 2018. Hubungan Dukungan Keluarga dengan Respon Psikologis Pasien Kanker Payudara yang Menjalani Kemoterapi di Poliklinik Onkologi RSUD Kabupaten Temanggung. Indonesian Journal of Nursing Research Vol. 1 No. 1, p. 1-9.

Riset Kesehatan Dasar, 2018. Hasil Utama Riset Kesehatan Dasar. Jakarta: Kementrian Kesehatan.

Sari. M , Dewi.Y, Utami. A. Hubungan Dukungan Keluarga Terhadap Motivasi Pasien Kanker Payudara Dalam Menjalani Kemoterapi Di Ruang Cendrawasih I RSUD Arifin Achmad Provinsi Riau. Jurnal Ners Indonesia, Vol. 2, No. 2: p. 158-161.

Sastra, L. 2016. Hubungan Dukungan Keluarga Dengan Konsep Diri Pasien Kanker Payudara.Jurnal Keperawatan Muhammadiyah 1(1), p. 7-12.

Smeltzer \& Bare. 2012. Keperawatan Medikal Bedah. Edisi 4. Jakarta: Salemba Medika.

Stuart, G.W., and Sundenen, S.J. 2013.Buku saku keperawatan jiwa.6 thediton. Jakarta: EGC.

Sudana, Chrisnawati \& Maratning. 2016. Gambaran Harga Diri Pada Pasien Kanker Payudara Yang Menjalani Kemotrapi Di RSUD Ulin Banjarmasin. Vol.1 Edisi.1 , p. 44-49. Suwistianisa. R , Huda. N \& Ernawaty. J. 2015. Faktor-Faktor Yang Mempengaruhi Tingkat Depresi Pada Pasien Kanker Yang Dirawat Di RSUD Arifin Achmad Provinsi Riau. JOM Vol 2 No 2: p. 1463-1473. 
Suyanto, Pramesty. N, \& Arumdari P. 2017.

Dukungan Keluarga pada Pasien

Kanker yang Menjalani Kemoterapi.

UNISSULA PRESS ( ISBN 978-602-

1145-69-2 ): p. 90-95.

Wahidin. 2015. Situasi penyakit kanker di Indonesia. Buletin Jendela Data dan Informasi Kesehatan Kementrian Kesehatan: Jakarta.

Yeny Husna. M , Dachriyanus. 2016. Dukungan Keluarga Memengaruhi Kepatuhan Pasien Hipertensi. Jurnal Keperawatan Indonesia, Vol. 19, 3, pISSN 1410-4490, eISSN 2 9203: p. 137-14. 